\title{
IDENTIFIKASI DIVISI PTERIDOPHYTA DI KAWASAN DANAU AUR KABUPATEN MUSI RAWAS
}

\author{
Reny Dwi Riastuti ${ }^{1}$, Sepriyaningsih ${ }^{2}$, Devi Ernawati ${ }^{3}$ \\ STKIP PGRI Lubuklinggau ${ }^{1,2,3}$ \\ renydwiriastuti09@gmail.com ${ }^{1}$
}

\begin{abstract}
ABSTRAK
Penelitian ini bertujuan untuk mengidentifikasi Divisi Pteridophyta di kawasan Danau Aur Kabupaten Musi Rawas. Metode penelitian yang digunakan adalah deskriptif kualitatif. Penelitian ini di buat 3 plot dengan ukuran $10 \mathrm{~m}$ x $10 \mathrm{~m}$. Berdasarkan hasil penelitian identifikasi divisi Pteridophyta di Kawasan Danau Aur adalah terdapat 5 ordo, 9 famili, 12 genus dan 19 spesies Pteris biaurita, Ploecnemia irreguler, Diplazium esculentum, Asplenium nidus, Gleichenia linearis, Christella dentata, Stenochlaena palastris, Diplazium esculentum, Davallia denticulata, Gleichenia linearis, Lygodium scandens, Lygodium circinatum, Nephrolepis exaltata, Nephrolepis cordifoli, Nephrolepis biserrata, Phymatosorus scolopendria, Selaginella wildenowii, Selaginella caudata dan Selaginella plana dengan suhu tanah di Kawasan Danau Aur Kabupaten Musi Rawas berkisar $27,5^{\circ} \mathrm{C}-31,5^{\circ} \mathrm{C}$ dengan derajat keasaman $(\mathrm{pH})$ tanah berkisar 5,116,18 .
\end{abstract}

Kata Kunci: divisi pteridophya, danau aur.

\section{ABSTRACT}

This study aims to identify the Pteridophyta Division in the Lake Aur Area of Musi Rawas Regency. The research method used is descriptive qualitative. This research was made in 3 plots with size $10 \mathrm{~m} \times 10 \mathrm{~m}$. Based on the result of identification research of Pteridophyta division in Aur Aurland area there are 5 orders, 9 families, 12 genus and 19 species Pteris biaurita, Ploecnemia irregular, Diplazium esculentum, Asplenium nidus, Gleichenia linearis, Christella dentata, Stenochlaena palastris, Diplazium esculentum, Davallia denticulata, Gleichenia linearis, Lygodium scandens, Lygodium circinatum, Nephrolepis exaltata, Nephrolepis cordifoli, Nephrolepis biserrata, Phymatosorus scolopendria, Selaginella wildenowii, Selaginella caudata and Selaginella plana with soil temperature in Aur Aur Area Musi Rawas Regency ranges $27,5^{\circ} \mathrm{C}-31,5^{\circ} \mathrm{C}$ with degree of acidity ( $\mathrm{pH}$ ) of land ranged from 5,11-6,18.

Keywords: pteridophya division, aur lake.

\section{PENDAHULUAN}

Indonesia banyak memiliki keanekaragaman flora dan faunanya. Ada 40 ribu spesies flora tumbuh di dunia, dan 30 ribu diantaranya hidup di Indonesi (Syukur, 2001). Ini berarti $75 \%$ flora hidup di Indonesia. Divisi Pteridophyta (paku) mudah sekali tumbuh, sehingga tersebar di seluruh bagian dunia, terkecuali 
di daerah kering (gurun). Divisi Pteridophyta (paku) tidak bisa hidup dilingkungan kering atau air yang terbatas, sebagian besar tumbuh di lingkungan basah/lembab atau daerah tropika (Mardiastutik, 2010). Indonesia merupakan daerah yang banyak ditumbuhi oleh divisi Pteridophyta (paku), karena Indonesia memiliki iklim Tropis.

Pteridophyta merupakan kingdom plantae Indonesia yang memiliki banyak spesies dengan persebaran yang luas. Persebaran ini 450 spesies terdapat di Jawa Barat, 333 spesies di Jawa Tengah dan 319 spesies terdapt di Jawa Timur. Pteridophyta dapat tumbuh pada lingkungan berair, permukaan tanah, ataupun menumpang pada tumbuhan lain yang disebut epifit. Pteridophyta bersifat epifit, karena sumber makanan tidak meyerap pada tubuh inang yang ditumpanginya, dan air yang diperoleh langsung dari lingkungan (Ulum, 2015). Menurut Suwila (2015) tumbuhan Pteridophyta epifit adalah tumbuhan yang hidupnya menempel dan menumpang pada tumbuhan lain sebagai penopang, tidak berakar pada tanah, berukuran lebih kecil dari tumbuhan penopang atau inang.

Danau Aur terletak di desa Sumber Jaya, Kecamatan Sumber Harta Kabupaten Musi Rawas. Danau Aur merupakan pusat irigasi, di bagian hulu terdapat rawa. Danau Aur berfungsi untuk mengaliri sawah daerah sumber harta. Dengan luas sekitar 40 hektar dan sedalam 20 meter, danau ini mulai berdiri pada tahun 2011. Danau Aur dikelilingi hutan. Karena pesona keindahannya, Danau Aur dijadikan destinasi wisata oleh warga setempat. Pada awal didirikannya, Danau Aur ini belum ramai. Namun, melihat potensi yang ada, maka pemerintah daerah kabupaten Musi Rawas akhirnya terus melakukan peningkatan pembangunan. Dampak dari pembangunan ini akan membuat ekosistem yang ada disekeliling Danau Aur terganggu.

Spesies dalam ekosistem yang ada disekeliling Danau Aur yang paling banyak adalah spesies dari devisi Pteridophyta. Penelitian tentang divisi Pteridophyta (paku) di Danau Aur belum pernah dilakukan, sehingga data mengenai keanekaragaman divisi Pteridophyta (paku) pun tidak ada, adapun tujuan penelitian ini adalah untuk mengidentifikasi Divisi Pteridophyta di kawasan Danau Aur Kabupaten Musi Rawas.

\section{METODE PENELITIAN}

\section{Rancangan Penelitian}

Metode dalam penelitian ini adalah metode deskriptif kualitatif. Penelitian deskriptif bertujuan untuk menjelaskan atau mendeskripsikan suatu keadaan atau peristiwa, objek, apakah orang atau semua yang terkait dengan variabel yang bisa dijelaskan baik dengan angka maupun kata-kata (Setyosari, 2015).

\section{Prosedur Penelitian}

Menurut Sari \& Rosada (2009) prosedur penelitiannya dilakukan beberapa tahap yang meliputi sebagai berikut: 
1. Melakukan survei pada lokasi penelitian yaitu kawasan Danau aur, lokasi yang dipilih tepat yaitu dengan melihat banyaknya divisi Pteridophyta (paku) pada lokasi yang akan dipilih. Setelah lokasi penelitian didapatkan berdasarkan hasil observasi yang telah dilakukan selanjutnya pembuatan plot tunggal sebanyak 3 plot secara acak dengan ukuran $10 \mathrm{~m}$ x $10 \mathrm{~m}$ dilokasi yang banyak terdapat divisi Pteridophyta (paku). Kegiatan selanjutnya melakukan pengambilan sampel untuk masing-masing jenis divisi Pteridophya (paku) yang terdapat didalam plot yang telah dibuat.

2. Dokumentasi spesimen tumbuhan paku, tujuan dari pemotretan/dokumentasi) spesimen adalah untuk mendapatkan bukti gambaran lengkap mengenai spesimen tersebut, tempat tumbuh serta ciri-ciri, baik warna serta morfologi tumbuhan paku, serta menghitung kerapatan tumbuhan paku.

3. Pembuatan deskripsi, setiap spesies paku yang ditemukan, maka dibuat suatu koleksi khusus secara lengkap dengan bagian-bagian yang dimilikinya serta mencatat kondisi tumbuhan paku secara langsung dalam keadaan yang masih segar di alam, hingga diperoleh data lengkap tentang tumbuhan paku.

4. Identifikasi tumbuhan paku, dilakukan dengan cara menggunakan kunci determinasi tumbuhan paku. Tumbuhan paku yang ada diamati adalah morfologi dalam kondisi masih segar.

5. Pembuatan herbarium dilakukan dengan cara membersihkan tumbuhan paku dari kotoran, lalu tumbuhan tersebut dimasukkan ke dalam kantong yang telah disemprot alkohol 70\%. Setelah itu tumbuhan dibentangkan dan disusun rapi di dalam kertas koran, lalu dikeringkan dengan diangin-anginkan, tanpa terkena sinar matahari. Tumbuhan yang telah kering selanjutnya diolesi alkohol $70 \%$, lalu ditempelkan pada karton putih dengan menggunakan solatif. Kemudian tempelkan label yang berisi identifikasi dan deskripsi.

\section{Teknik Pengumpulan Data}

Teknik pengumpulan data dimulai dengan survei lokasi kemudian pembuatan plot petak tunggal berukuran $10 \mathrm{~m} \times 10 \mathrm{~m}$, pengambilan dokumentasi, pengambilan sampel selama penjelajahan untuk pembuatan herbarium. Teknik pengumpulan data didukung juga dengan data sekunder yang meliputi pengukuran pH tanah, kelembapan tanah dan suhu/kelembapan udara,

\section{Teknik Analisis Data}

Pengolahan data dikumpulkan selanjutnya dianalisis secara kualitatif untuk memperoleh informasi tentang tumbuhan paku yang ada di lokasi tempat penelitian dan disajikan dalam bentuk gambar, dan uraian deksripsi dengan cara mencocokkan divisi Pteridophyta (paku) dengan buku flora (Steenis, 2013), buku taksonomi tumbuhan (Tjitrosoepomo, 2011), dan buku botani umum 3 (Tjitrosoepomo, et al. 2010). Jika ada divisi Pteridophyta (paku) yang tidak teridentifikasi dapat menggunakan cara kunci determinasi. 


\section{HASIL PENELITIAN}

Hasil identifikasi keanekaragaman divisi Pteridophyta (paku) di Kawasan Danau Aur Kabupaten Musi adalah terdapat 5 Ordo, 9 famili, 12 Genus dan 18 Spesies, dapat dilihat pada tabel di bawah:

Tabel.1 Hasil Keanekaragaman Divisi Pteridophyta (Paku)

\begin{tabular}{|c|c|c|c|}
\hline Ordo & Family & Genus & Spesies \\
\hline \multirow{10}{*}{ 1. Polypodiales } & Pteridaceae & Pteris & Pteris biaurita \\
\hline & \multirow{5}{*}{ Dryopteridaceae } & Stenochlaenae & Stenochlaenae palastris \\
\hline & & Ploecnemia & Ploecnemia irregularis \\
\hline & & & Nephrolepis exaltata \\
\hline & & Nephrolepis & Nephrolepis cordifolia \\
\hline & & & Nephrolepis biserrata \\
\hline & \multirow{2}{*}{ Polypodiaceae } & Diplazium & Diplazium esculentum \\
\hline & & Phymatosorus & Phymatosorus scolopendria \\
\hline & Aspleniaceae & Asplenium & Asplenium nidus \\
\hline & Davalliaceae & Davallia & $\begin{array}{l}\text { Davallia denticulata } \\
\text { Davallia solida }\end{array}$ \\
\hline 2. Gleicheniales & Gleicheniaceae & Gleichenia & Gleichenia linearis \\
\hline 3. Schizaeles & Lygodiaceae & Lygodium & $\begin{array}{l}\text { Lygodium scandens } \\
\text { Lygodium circinatum }\end{array}$ \\
\hline 4. Filicales & Thelypteridaceae & Christella & Christella dentata \\
\hline 5. Selaginellales & Selaginellaceae & Selaginella & $\begin{array}{l}\text { Selaginella wildenowii } \\
\text { Selaginella caudata } \\
\text { Selaginella plana }\end{array}$ \\
\hline
\end{tabular}

Tabel.2 Hasil Keanekaragaman Divisi Pteridophyta (Paku) pada Plot 1-3

\begin{tabular}{|c|c|c|c|c|c|c|}
\hline No & Plot & $\begin{array}{c}\text { pH } \\
\text { Tanah }\end{array}$ & $\begin{array}{c}\text { Suhu } \\
\text { Lingkungan }\end{array}$ & Ordo & Genus & Spesies \\
\hline \multirow[t]{7}{*}{1.} & Plot 1 & 6,16 & $28,5^{\circ} \mathrm{C}$ & Polypodiales & Pteris & Pteris biaurita \\
\hline & & & & & Ploecnemia & Ploecnemia irreguler \\
\hline & & & & & $\overline{\text { Diplazium }}$ & Diplazium esculentum \\
\hline & & & & & Asplenium & Asplenium nidus \\
\hline & & & & Gleicheniales & Gleichenia & Gleichenia linearis \\
\hline & & & & $\overline{\text { Filicales }}$ & Christella & Christella dentata \\
\hline & & & & Selaginalles & Selaginella & Selaginella caudata \\
\hline \multirow[t]{6}{*}{2.} & Plot 2 & 5,11 & $27,5^{\circ} \mathrm{C}$ & Polipodiales & Stenochlaena & Stenochlaena palastris \\
\hline & & & & & Ploecnemia & Ploecnemia irreguler \\
\hline & & & & & Diplazium & Diplazium esculentum \\
\hline & & & & & Davallia & $\begin{array}{l}\text { Davallia denticulata dan } \\
\text { Davallia solida }\end{array}$ \\
\hline & & & & Gleicheniales & Gleichenia & Gleichenia linearis \\
\hline & & & & Schizaeles & Lygodium & $\begin{array}{l}\text { Lygodium scandens dan } \\
\text { Lygodium Circinatum }\end{array}$ \\
\hline
\end{tabular}




\begin{tabular}{|c|c|c|c|c|c|}
\hline 3. Plot 3 & 6,18 & $31,5^{\circ} \mathrm{C}$ & Polypodiales & Pteris & Pteris biaurita \\
\hline & & & & Nephrolepis & $\begin{array}{l}\text { Nephrolepis exaltata, } \\
\text { Nephrolepis cordifolia } \\
\text { dan Nephrolepi biserrata }\end{array}$ \\
\hline & & & & Phymatosorus & $\begin{array}{l}\text { Phimatosorus } \\
\text { scolopendria }\end{array}$ \\
\hline & & & Selaginellales & Selaginella & $\begin{array}{l}\text { Selaginella wildenowii } \\
\text { Selaginella caudata } \\
\text { Selaginella plana }\end{array}$ \\
\hline
\end{tabular}

\section{PEMBAHASAN}

Pembahasan pada penelitian ini berdasarkan hasil pengamatan divisi Pteridophyta (paku) pada plot 1-3 di Kawasan Danau Aur.

1. Hasil pengamatan divisi Pteridophyta (paku) di kawasan Danau Aur Kabupaten Musi Rawas pada plot 1 berjumlah 7 spesies Pteris biaurita, Ploecnemia irreguler, Diplazium esculentum, Asplenium nidus, Gleichenia linearis, Christella dentata dan Selaginella caudata. Suhu lingkungan $28,5^{\circ} \mathrm{C}$ dan derajat keasaman $\mathrm{pH}$ tanah 6,16. Hasil identifikasi keanekaragaman divisi Pteridophyta (paku) pada plot 1 di Kawasan Danau Aur Kabupaten Musi Rawas sebagai berikut:

\section{Pteris biaurita}

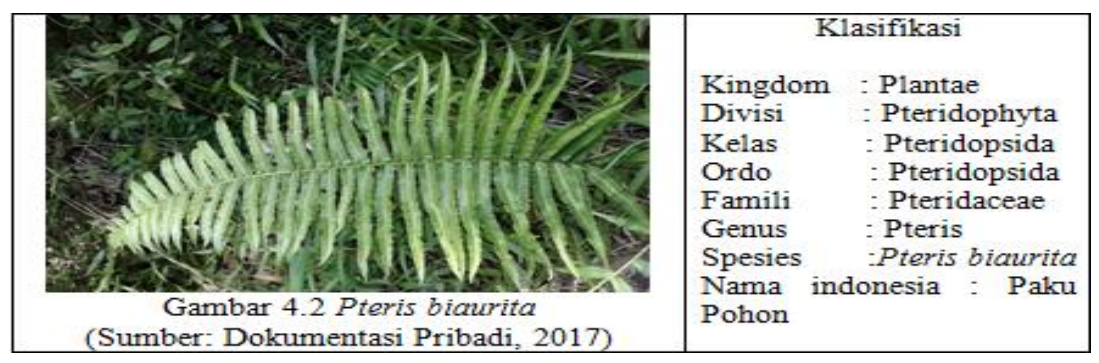

Termasuk famili Pteridaceae yaitu Pteris biaurita, yang tumbuh ditempat yang lembab. Tumbuhan ini mempunyai batang yang pendek, tegak, ditutupi oleh akar-akar langsing, tangkai daun hijau, bagian atas bertekuk, ujung tangkai daun berlekuk. Sisik-sisik pada ujung batang dan bagian pangkal tangkai daun bewarna coklat tua, daun utama berjumlah 11 daun berhadapan dalam satu tangkai, setiap daun utama tersusun dari 23 pasang helai anak daun berjumlah , kedudukan daun utama sejajar. Testur daun tipis, berdasarkan $\mathrm{pH}$ tanah yang dilihat pada plot tempat di temukan paku Pteris biaurita bahwa paku Pteris biaurita di temukan pada $\mathrm{pH}$ tanah 6,16 yang berarti asam. Suhu lingkungan yang di lihat pada plot tempat ditemukan paku Pteris biaurita bahwa paku Pteris biaurita hidup atau banyak di temukan pada suhu $28^{\circ} \mathrm{C}$ $31^{\circ} \mathrm{C}$ yang berarti suhu relatif normal untuk pertumbuhan paku.

Menurut Hartini (2006) tangkai daun berwarna hijau atau keunguan, berlilin, dengan panjang 30-60 cm, bagian atas tertekuk. Tangkai anak daun 
dan tulang daun berlekuk dalam. Daun majemuk ganda, helaian daun panjang 30-45 cm, dan lebar 25-30 cm. Daun fertil lebih sempit dari daun steril, berlekuk dalam, anak daun saling berhadapan atau hampir dengan 5-9 pasang anak daun dan anak daun ujung, anak daun paling bawah paling panjang dan bercabang, yang lain tidak bercabang, tidak bertangkai, bagian ujung meruncing. Anak daun fertil lebih sampai $3,5 \mathrm{~cm}$, daun steril sampai $4.5 \mathrm{~cm}$, berlekuk dalam, 3-4 mm dari tulang daun, memanjang, membulat, tekstur tipis. Pteris biaurita biasanya terdapat didaratan rendah maupun daerah pegunungan, di tempat yang lembab dan ternaungi. Jenis ini tersebar di daerah tropis dan berpotensi sebagai tanaman hias.

Ploecnemia irregularis

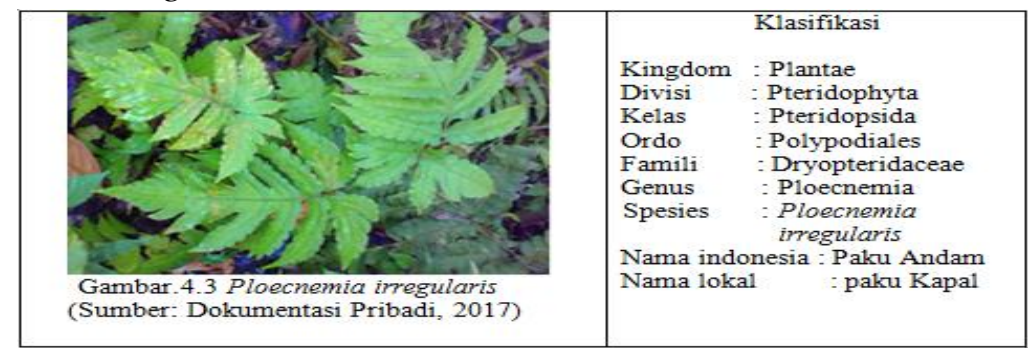

Famili DryoPteridophyta, spesies Ploecnemia irregularis merupakan tanaman paku berukuran besar yang hidup di atas permukaan tanah (terestial) dan hidup ditempat yang lembab. Batang pendek dan tumbuh tegak, warna daun hijau gelap dan pada daun muda warnanya lebih pucat, ditutupi sisik yang rapat. Sisiknya tipis, dengan panjang antara $4-5 \mathrm{~cm}$. Berdasarkan $\mathrm{pH}$ tanah yang dilihat pada plot tempat di temukan paku Ploecnemia irreguler bahwa paku Ploecnemia irreguler di temukan pada $\mathrm{pH}$ tanah 6,16 yang berarti asam. Suhu lingkungan yang di lihat pada plot tempat ditemukan paku Ploecnemia irreguler adalah suhu $28^{\circ} \mathrm{C}-31^{\circ} \mathrm{C}$ yang berarti suhu relatif normal untuk pertumbuhan paku. Menurut Tjitrosoepomo (2011) daunnya berstruktur bipinnatifid, dengan pinnules terbawah berukuran sangat besar, batang pendek dan tumbuh tegak. Bagian ujung ditutupi oleh sisik yang rapat. Sisisknya tipis, linear panjang antara 3-4 cm, dan bewarna coklat gelap helai daunnya berukuran panjang $50-200 \mathrm{~cm}$ dan lebarnya $60-70 \mathrm{~cm}$. Pada daun muda, warnanya lebih pucat dan menarik perhatian.

\section{Diplazium esculentum}

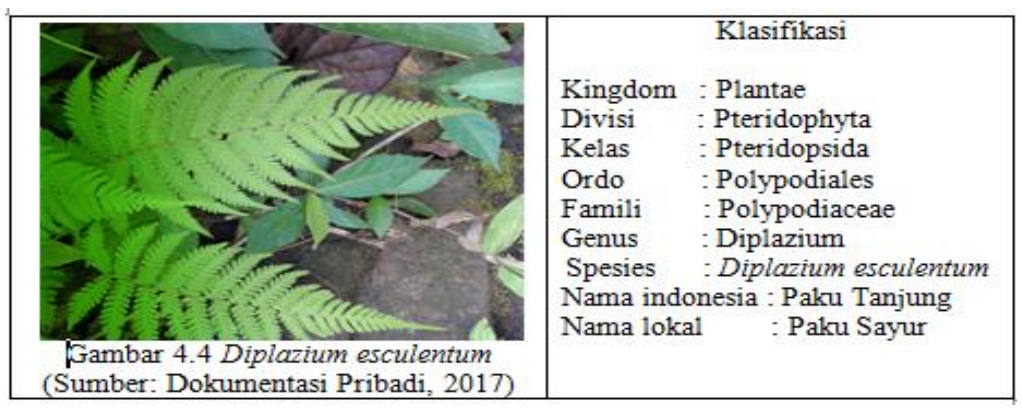


Famili Polypodiaceae jenis Diplazium esculentum. Mempunyai rimpang pendek merayap $5 \mathrm{~mm}$. Tekstur daun agak kaku dengan tepi bergigi bewarna hijau gelap, ditemukan ditempat yang berbatuan. Tersusun atas 21 pasang anak-anak daun, batang gelap tampak berdaging. Akar serabut hitam, daun muda sering digunakan masyarakat sebagai bahan sayuran. Berdasarkan $\mathrm{pH}$ tanah yang dilihat pada plot tempat di temukan paku Diplazium esculentum bahwa paku Diplazium esculentum di temukan pada $\mathrm{pH}$ tanah 6,16 yang berarti asam. Suhu lingkungan yang di lihat pada plot tempat ditemukan paku Diplazium esculentum bahwa paku Diplazium esculentum hidup atau banyak di temukan pada suhu $28^{\circ} \mathrm{C}-31^{\circ} \mathrm{C}$ yang berarti suhu relatif normal untuk pertumbuhan paku.

Menurut Tjitrosomo, (2010) mengungkapkan daun pakis tinggi $100 \mathrm{~cm}$ sebesar $20 \mathrm{~cm}$. Daun majemuk, menyirip, lanset, tepi bergigi, ujung runcing, pangkal tumpul, pertulangan menyirip, panjang mencapai 5-6 cm, lebar 1-2 $\mathrm{cm}$. Tersusun atas 15 pasang anak-anak daun panjangnya $40 \mathrm{~cm}$ dan lebarnya 8 $\mathrm{cm}$. Batang gelap nampak berdaging dengan ental banyak mencapai panjang 1,2 m lebih. Akar serabut, hitam. Sori tumbuh di sepanjang urat anak daun pada ketiak anak daun tumbuh tunas untuk perbanyakan diri. Daun muda jauh lebih diinginkan dan dimakan disemua bagian baik mentah atau dimasak. Paku ini sering digunakan sebagai sayuran, atau sebagai bahan minuman. Tunas muda tumbuhan ini dapat digunakan untuk bahan makanan baik dimakan langsung, disayur, ditumis atau dikukus.

Asplenium nidus

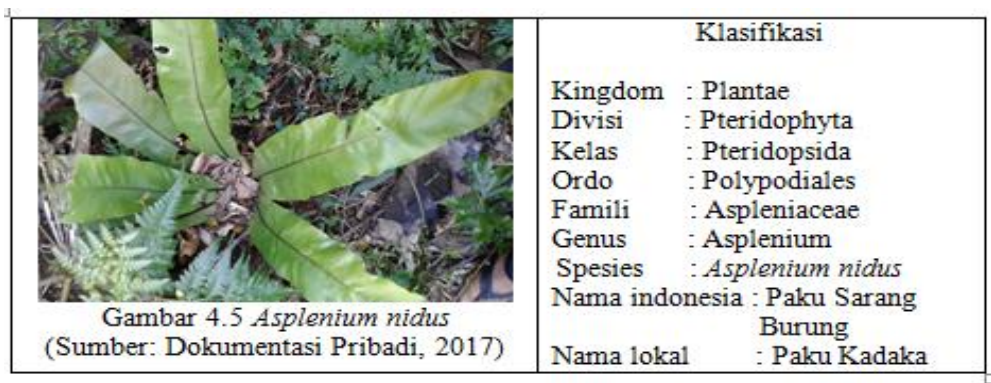

Famili Aspleniaceae jenis Asplenium nidus, ditemukan dibawah pohon besar dan lembab. Paku ini hidup epifit dengan akar yang kuat, bagian ujung mendukung daun-daun yang tersusun roset, di bagian bawahnya terdapat kumpulan akar yang besar dan rambut berwarna coklat, bagian ujung ditutupi sisik-sisik sepanjang sampai $2 \mathrm{~cm}$, berwarna coklat hitam. Tangkai daun berwarna hitam dengan panjang sekitar $5 \mathrm{~cm}$. Tulang daun menonjol di atas permukaan atas daun dan hampir rata kebawah, bewarna coklat tua. Daun muda bewarna hijau pucat dan pada daun tua bewarna hijua tua. Tekstur daun seperti kertas, panjang daun sampai $140-150 \mathrm{~cm}$, dan lebar sampai $20 \mathrm{~cm}$. Berdasarkan $\mathrm{pH}$ tanah yang dilihat pada plot tempat di temukan paku Asplenium nidus bahwa paku Asplenium nidus di temukan pada $\mathrm{pH}$ tanah 6,16 yang berarti asam. Suhu lingkungan yang di lihat pada plot tempat ditemukan paku 
Asplenium nidus bahwa paku Asplenium nidus hidup atau banyak di temukan pada suhu $28^{\circ} \mathrm{C}-31^{\circ} \mathrm{C}$ yang berarti suhu relatif normal untuk pertumbuhan paku.

Menurut Hartini (2006) daun tunggal, panjang mencapai $150 \mathrm{~cm}$, demgan lebar sampai $20 \mathrm{~cm}$, ujung daun meruncing. Tulang daun menonjol di permukaan atas daun, biasanya hampir rata ke bawah, berwarna coklat tua pada daun tua. Tekstur daun seperti kertas. Jenis ini sudah umum untuk tanaman hias, selain itu juga dapat digunakan sebagai obat tradisional antaranya sevagai penyubur rambut, obat demam, obat kontrasepsi, depuratif dan sedatip.

\section{Gleichenia linearis}

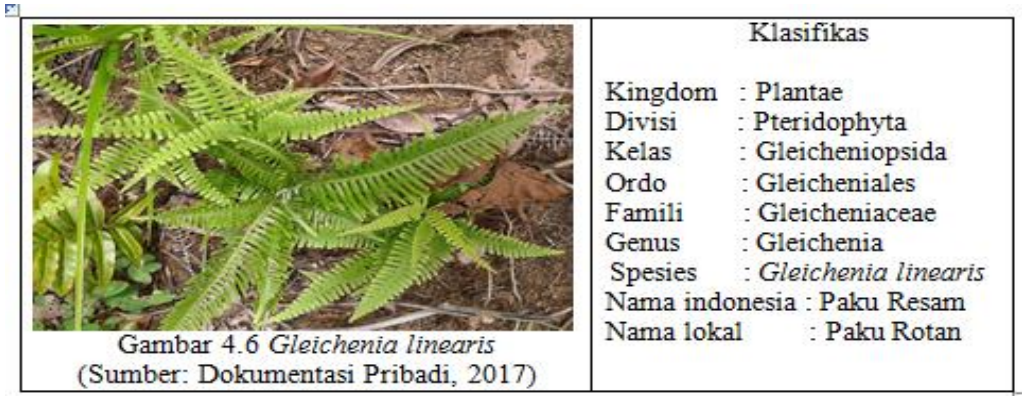

Famili Gleicheniaceae jenis Gleichenia linearis, ditemukan dibawah pohon yang rindang dan tempat yang lembab. Memiliki percabangan yang khusus sehingga masing-masing cabang akan mempunyai cabang lagi sampai menutupi tanah. Paku ini merupakan tumbuhan semak yang sering mendominasi suatu daerah atau temapat. Berdasarkan $\mathrm{pH}$ tanah yang dilihat pada plot tempat di temukan paku Gleichenia linearis bahwa paku Gleichenia linearis di temukan pada $\mathrm{pH}$ tanah 6,16 yang berarti asam. Suhu lingkungan yang di lihat pada plot tempat ditemukan paku Gleichenia linearis bahwa paku Gleichenia linearis hidup pada suhu $28^{\circ} \mathrm{C}-31^{\circ} \mathrm{C}$ yang berarti suhu relatif normal untuk pertumbuhan paku.

Menurut Purwanti (2014) paku ini memiliki percabangan yang khusus sehingga jenis ini mudah dikenal. setiap cabang akan bercabang lagi begitu seterusnya sehingga seluruh tubuh menutupi tanah tempat hidupnya, berkembang biak dengan menggunakan akarnya. Tunas yang tumbuh dari akar akan bewarna hijau pucat yang ditutupi oleh bulu-bulu warna hitam. Batangnya keras berkayu dan bewarna kuning kecoklatan.

Daun bikotom, tinggi bisa mencapai $3 \mathrm{~m}$. rhizom panjang, sporangia tanpa indusium, spora trilet, tetrahendral. Sori terdapat pada setiap anak daun dan persebarannya terbatas disepanjang tulang daunnya. Hidup di daerah subtropis dan tropis. Habitat higrofit, dimanfaatkan untuk obat, kulit batangnya digunakan untuk bahan baku kerajinan tangan. Bagian dalam batangnya dianyam untuk membuat kopiah (Yusuf, 2009).

\section{Christella dentata}




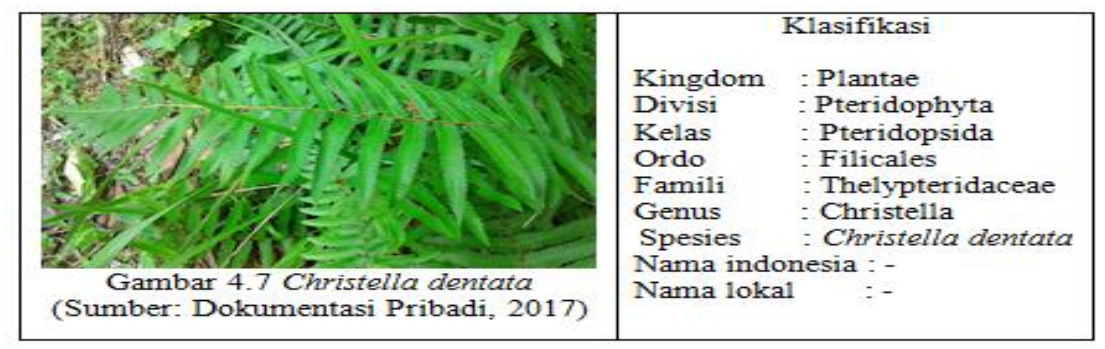

Termasuk dalam jenis paku tanah karena tumbuhnya ditanah, sering dijumpai di daerah berbatuan dan lembab. Famili Thelypteridaceae jenis Christella dentata, akarnya menjalar pada permukaan bebatuan dan juga akarakarnya masuk ke celah-celah batu. Akar sejati bewarna gelapdan bercabangcabang, dimanfaat sebagai sayur-sayuran oleh masyarakat setempat. Berdasarkan $\mathrm{pH}$ pada plot tempat di temukan paku Christella dentata bahwa paku Christella dentata di temukan pada $\mathrm{pH}$ tanah 6,16 yang berarti asam. Suhu lingkungan pada plot adalah $28^{\circ} \mathrm{C}-31^{\circ} \mathrm{C}$ yang berarti suhu relatif normal untuk pertumbuhan paku.

Menurut Tjitrosomo (2011) memiliki akar sejati bewarna gelap bertipe akar serabut yang bercabang-cabang secara dikotom. Terdapat ramenta pada batang yang bewarna coklat. Susunan Ramenta sangat rapat sehingga seperti membentuk sebuah lapisan padat. Termasuk tumbuhan herba dengan percabangan tangkai daun yang sangat dekat dengan tanah sehingga batang sulit terlihat jelas. Bermanfaat sebagai sayur-sayuran, obat-obatan dan sebagai tanaman hias

\section{Selaginella caudata}

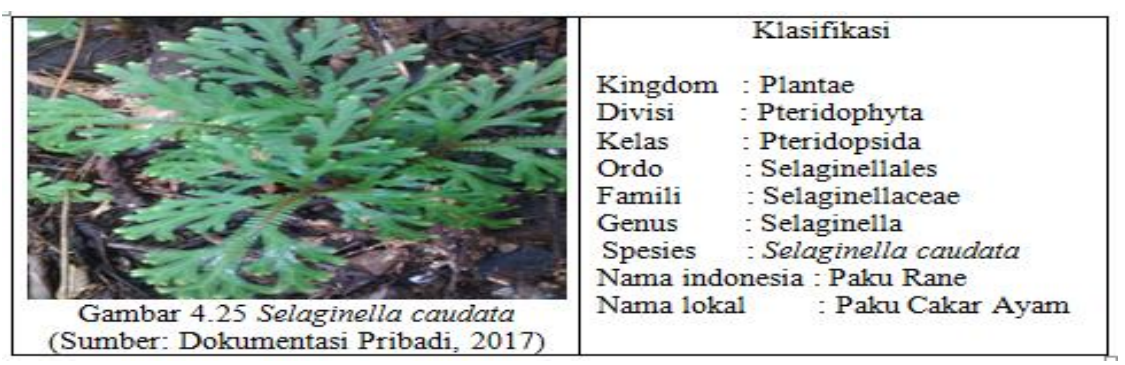

Famili Selaginellaceae jenis Selaginella caudata, ditemukan ditempat yang lembab dan berbatuan. Daun tersusun berhadapan, memiliki batang yang berdiri tegak dan sebagian berbaring, batang bercabang menggarpu, daun bewarna hijau. Berdasarkan $\mathrm{pH}$ tanah yang dilihat pada plot tempat di temukan paku Selaginella caudata bahwa paku Selaginella caudata di temukan pada $\mathrm{pH}$ tanah 6,16 yang berarti asam. Suhu lingkungan pada plot tempat ditemukan paku Selaginella caudata pada suhu $28^{\circ} \mathrm{C}-31^{\circ} \mathrm{C}$ yang berarti suhu relatif normal untuk pertumbuhan paku.

Menurut Tjitrosoepomo (2011) batang berbaring dan sebagian tegak, batang bercabang-cabang menggarpu dan tidak memperlihatkan pertumbuhan sekunder. Memiliki akar-akar yang keluar dari bagian batang yang tidak memiliki daun dan dinamakan pendukung akar. Daun tersusun berhadapan, 
sepasang (ligula). Ligula berfungsi sebagai alat penghisap air (misalnya tetes air hujan) dan seringkali dengan perantaraan suatu trakeida mempunyai hubungan dengan batas pembuluh pengangkutan. Habitat tumbuh di tanah atau dapat epifit pada bebatuan.

2. Hasil pengamatan divisi Pteridophyta (paku) di kawasan Danau Aur Kabupaten Musi Rawas pada plot 2 berjumlah 7 spesies, yaitu Stenochlaena palastris, Ploecnemia irreguler, Diplazium esculentum, Davallia denticulata, Gleichenia linearis, Lygodium scandens dan Lygodium circinatum. spesies paling banyak ditemukan adalah spesies Gleichenia linearis berjumlah 80 spesies dan jenis spesies yang paling sedikit ditemukan adalah jenis spesies Diplazium esculentum berjumlah hanya 2 spesies. Dengan suhu lingkungan $27,5^{\circ} \mathrm{C}$ dan derajat keasaman $\mathrm{pH}$ tanah 5,11. Hasil identifikasi keanekaragaman divisi Pteridophyta (paku) pada plot 2 di Kawasan Danau Aur Kabupaten Musi Rawas sebagai berikut:

\section{Stenochlaenae palustris}

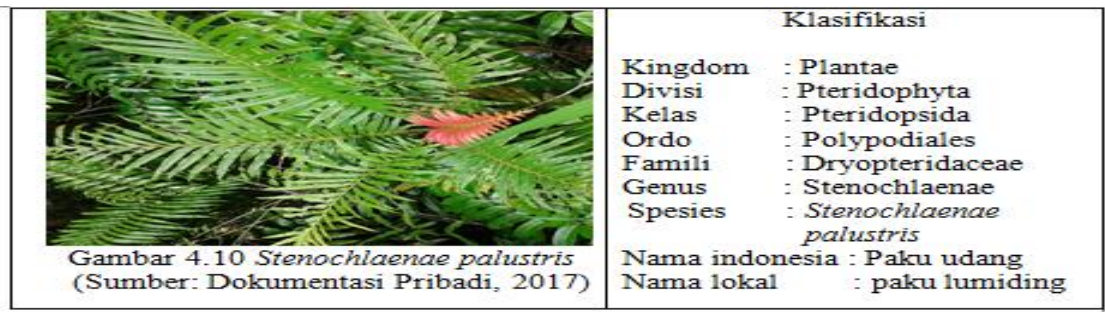

Famili Dryopteridaceae jenis Stenochlaenae palustris, ditemukan pada tempat yang lembab dibawah pohon. Daun tua berwarna hijau tua dan daun muda berwarna kemerahan. Anak daun banyak bertangkai pendek. Termasuk paku tanah, panjang 5-10 m. Akar kuat memanjat tinggi, berbentuk pipih persegi telanjang atau bersisik sangat jarang, kerap kali dengan tunas arah merayap, yang kadang-kadang merayap di atas permukaan atau tanah kearah batang dekatnya, daun menyirip tunggal, tangkai daun 10-20 cm, kuat. Daun steril keunguan, berbentuk lanset, lebar 1,5- $4 \mathrm{~cm}$, meruncing dengan kaki lancip, baji atau membulat,kedua sisi tidak sama, di atas kaki bergerigi tajam dan halus, urat daun berjarak lebar. Lebar anak daun hanya 2-5 mm. pH tanah adalag 5,11 yang berarti asam. Suhu lingkungan adalahSS $28^{\circ} \mathrm{C}-31^{\circ} \mathrm{C}$ yang berarti suhu relatif normal untuk pertumbuhan paku.

\section{Ploecnemia irregularis}

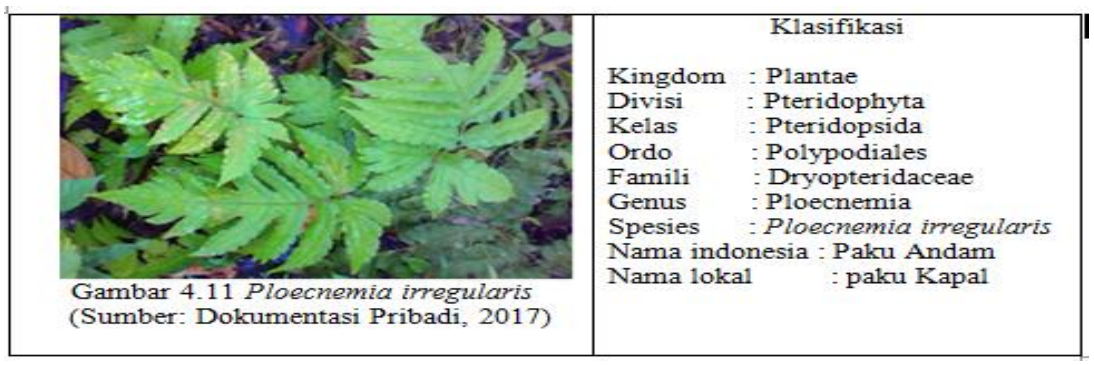


Famili DryoPteridophyta jenis Ploecnemia irregularis merupakan tanaman paku berukuran besar yang hidup di atas permukaan tanah (terestial) dan hidup ditempat yang lembab. Batang pendek dan tumbuh tegak, warna daun hijau gelap dan pada daun muda warnanya lebih pucat, ditutupi sisik yang rapat. Sisiknya tipis, dengan panjang antara 4-5 cm dan bewarna coklat gelap, ukuran panjang helai daun 50-200 cm dan lebar 60-70 cm. Berdasarkan pH tanah 5,11 yang berarti asam. Suhu lingkungan yang di lihat pada plot tempat ditemukan paku Ploecnemia irreguler bahwa paku Ploecnemia irreguler hidup atau banyak di temukan pada suhu $28^{\circ} \mathrm{C}-31^{\circ} \mathrm{C}$ yang berarti suhu relatif normal untuk pertumbuhan paku.

Diplazium esculentum

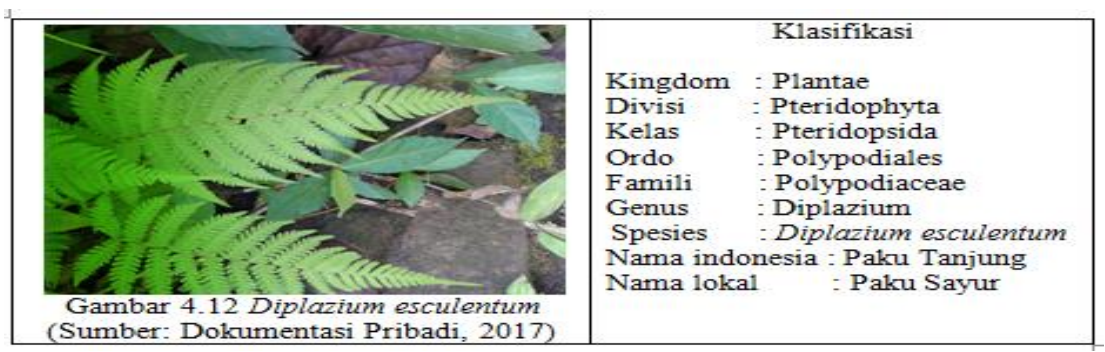

Famili Polypodiaceae jenis Diplazium esculentum. mempunyai akar pendek merayap $5 \mathrm{~mm}$. Tekstur daun agak kaku dengan tepi bergigi bewarna hijau gelap, ditemukan ditempat yang berbatuan. Tersusun atas 21 pasang anak-anak daun, batang gelap tampak berdaging. Akar serabut hitam, daun muda sering digunakan masyarakat sebagai bahan sayuran. $\mathrm{pH}$ tanah 5,11 yang berarti asam. Suhu lingkungan adalah $28^{\circ} \mathrm{C}-31^{\circ} \mathrm{C}$ yang berarti suhu relatif normal untuk pertumbuhan paku.

Menurut Tjitrosomo (2010) mengungkapkan daun paku ini merupakan majemuk, de gan susunan tulang daun menyirip, dan dan helai berbentuk lanset, tepi bergigi, ujung runcing, pangkal tumpul, panjang 5-6 cm, lebar 1-2 $\mathrm{cm}$, tangkai silindris dan berambut. Anak daun panjangnya $40 \mathrm{~cm}$, lebar $8 \mathrm{~cm} \mathrm{~d}$ saling berpasangan. Warna batang gelap nampak berdaging dengan ental banyak mencapai panjang 1,2 m lebih. Akar serabut dan berwarna hitam. Daun muda dapat digunakan sebagai sayuran karena bisa dimakan

Davallia denticulata

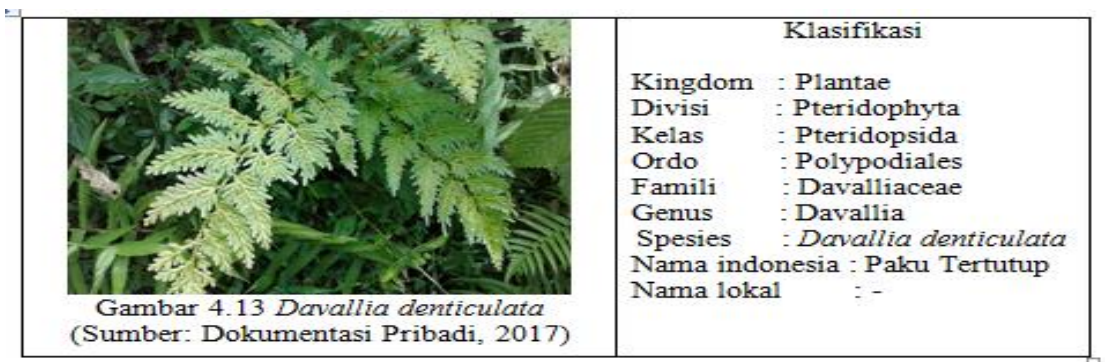

Famili Davalliaceae jenis Davallia denticulata, ditemukan pada tempat yang terbuka dan diatas batang pohon, daun majemuk dan berbentuk segitiga. Akar panjang, bersisik rapat dapat menjalar. $\mathrm{pH}$ tanah adalah 5,11 yang berarti 
asam. Suhu lingkungan adalah $28^{\circ} \mathrm{C}-31^{\circ} \mathrm{C}$ yang berarti suhu relatif normal untuk pertumbuhan paku.

Menurut Arini \& Kinho (2012) Epifit memiliki tinggi 0,75-1,30 m. Akar panjang, bersisik rapat dengan sisik lebar (pada pangkal lebar 1,5-4 mm, dengan ujung yang berambut pendek, panjang 8-20 mm) dapat menjalar. Daun berbentuk bulat telur segitiga, 60-100 kali 40-70 cm, pertulangan daun menyirip rangkap 3-4, tangkai $15-60 \mathrm{~cm}$, anak daun bulat telur memanjang, beringgit bergigi. Ujung tajuk daun muncul tinggi diatas sorus, selaput penutup terikat sepanjang pangkal daun tepi samping, berbentuk piala, membuka keluar. Habitat menumpang pada batang tanaman dihutan (Steenis, 2013).

\section{Davallia Solida}

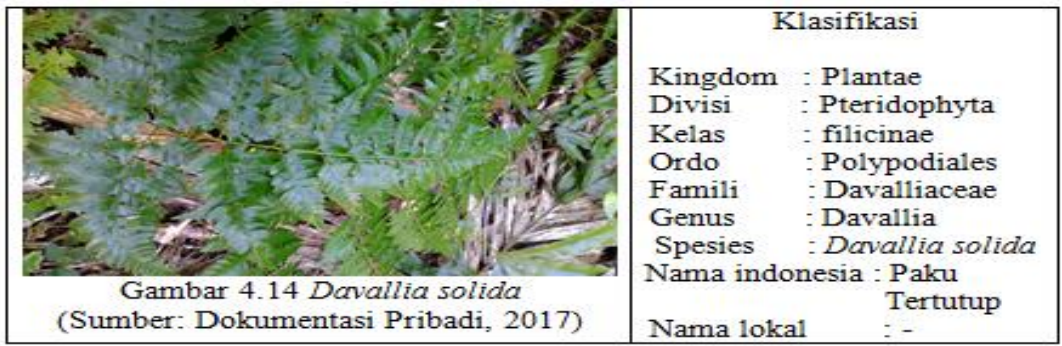

Famili Davalliaceae jenis Davallia solida, ditemukan pada tempat yang lembab. Helaian daun berbentuk segitiga dengan bentuk tepi bergigit, memiliki tekstur kaku dan kuat, permukaan daun mengkilat. Tangkai berwarna coklat gelap dan mengikilap, banyak di manfaatkan oleh masyarakat sebagai tanaman hias. Daun majemuk menyirip ganda dengan helaian daunnnya berbentuk segitiga dengan tepi yang beringgit, kaku dan kuat, permukaan daun mengkilat. Rimpang merayap panjang, kuat dan berdaging. Pada saat muda rimpangnya ditutupi oleh sisik-sisik yang padat, warnanya coklat terang. Entalnya berjumbai, panjangnya sampai $1 \mathrm{~m}$. Ental berbentuk segitiga, dan menyirip ganda tiga atau empat. Tangkainya berwarna coklat gelap, mengkilat. Sorus benbentuk corong dengan indusium. Spora tetrahedral. Hidup higrofit, sebagai epifit. Berdasarkan $\mathrm{pH}$ tanah yang dilihat pada plot tempat di temukan paku Davallia solida bahwa paku Davallia solida di temukan pada $\mathrm{pH}$ tanah 5,11 yang berarti asam. Suhu lingkungan adalah $28^{\circ} \mathrm{C}-31^{\circ} \mathrm{C}$ yang berarti suhu relatif normal untuk pertumbuhan paku, dimanfaatkan sebagai tanaman hias (Yusuf, 2009).

Gleichenia linearis

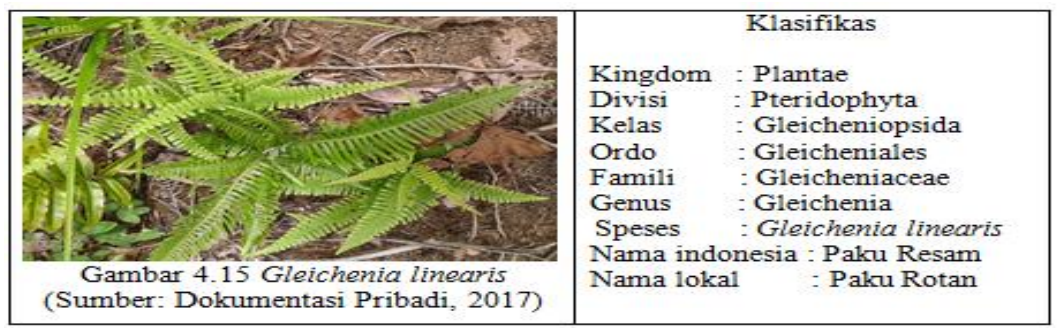


Famili Gleicheniaceae jenis Gleichenia linearis, ditemukan dibawah pohon yang rindang dan tempat yang lembab. Memiliki percabangan yang khusus sehingga masing-masing cabang akan bercabang lagi sampai seterusnya hingga menutupi tanah. Paku ini berupa tumbuhan semak yang sering mendominasi suatu daerah atau temapat. Berdasarkan $\mathrm{pH}$ tanah yang dilihat pada plot tempat di temukan paku Gleichenia linearis bahwa paku Gleichenia linearis di temukan pada $\mathrm{pH}$ tanah 5,11 yang berarti asam. Suhu lingkungan adalah $28^{\circ} \mathrm{C}-31^{\circ} \mathrm{C}$ yang berarti suhu relatif normal untuk pertumbuhan paku.

Menurut Purwanti (2014) paku ini memiliki pecabangan yang khusus sehingga jenis ini mudah dikenal. Setiap cabang akan bercabang lagi begitu seterusnya sehingga seluruh tubuh menutupi tanah tempat hidupnya, berkembang biak dengan menggunakan akarnya. Tunas yang tumbuh dari akar akan bewarna hijau pucat yang ditutupi oleh bulu-bulu warna hitam, dimanfaatkan untuk obat, kulit batangnya digunakan untuk bahan baku kerajinan tangan. Bagian dalam batangnya dianyam untuk membuat kopiah (Yusuf, 2009).

\section{Lygodium scandens}

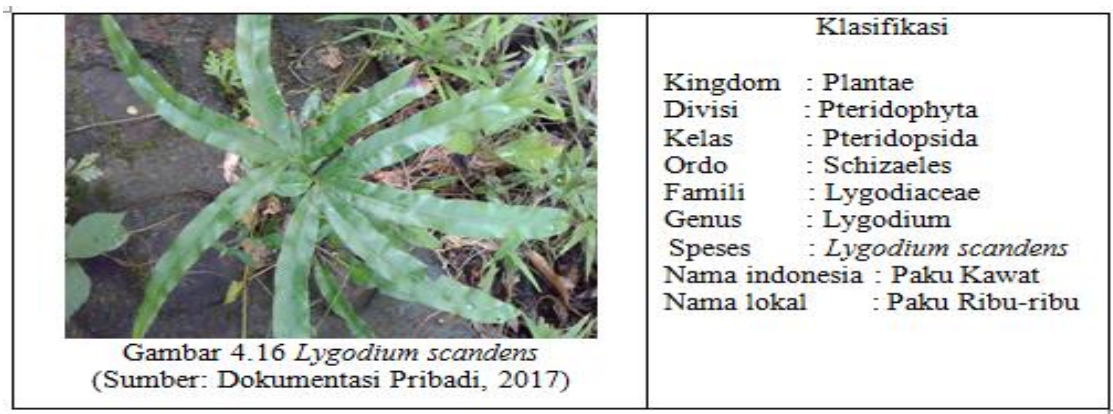

Spesies Lygodium scandens dikenal dengan nama daerah ribu-ribu garege termasuk kedalam famili Lygodiaceae, ditemukan ditempat yang lembab dan menompang pada tumbuhan lain. Daun berwarna hijau muda, tipis dan permukaannya licin. Daunnya membelit tumbuhan lain yang berada didekatnya. Daun muda lebih kecil dari daun tua. Batang kuat namun licin.daun berbentuk segitiga memanjang seperti jantung, ujung daun tumpul dan bergerigi yang lebih dalam. Daun tersusun menyirip berseling, berdasarkan $\mathrm{pH}$ tanah yang dilihat pada plot tempat di temukan paku Lygodium scandens bahwa paku Lygodium scandens di temukan pada $\mathrm{pH}$ tanah 5,11 yang berarti asam. Suhu lingkungan yang di lihat pada plot tempat ditemukan paku Lygodium scandens bahwa paku Lygodium scandens hidup atau banyak di temukan pada suhu $28^{\circ} \mathrm{C}-31^{\circ} \mathrm{C}$ yang berarti suhu relatif normal untuk pertumbuhan paku.

Berakar di tanah namun daunnya membelit tumbuhan lain yang berada didekatnya. Mempunyai batang bulat, kecil dan licin namun kuat. Cabang berwarna coklat kehijauan. Daun majemuk tersusun menyirip berseling dengan 4-6 anak daun pada setiap sisinya. Daun berwarna hijau muda, tipis dan kedua 
permukaannya licin. Daun berbentuk segitiga seperti jantung. Ujung daun tumpul dengan tepi daun bergerigi. Daun fertil berukuran lebih kecil dari daun steril, namun lebih lebar sehingga bentuknya hampir membulat. Daun fertil memiliki gerigi yang lebih dalam. Sporangium berwarna hijau muda tersusun dalam dua baris pada tepi daun fertil. Lygodium scandens tumbuh merambat pada tanaman lain. Mempunyai daun kecil, bergerigi, berwarna hijau pucat dengan basalnya yang melebar sehingga mempunyai bentuk segitiga. Sporangium terletak di ujung-ujung gerigi daun fertil (Purwanti, et al. 2014).

Lygodium circinatum

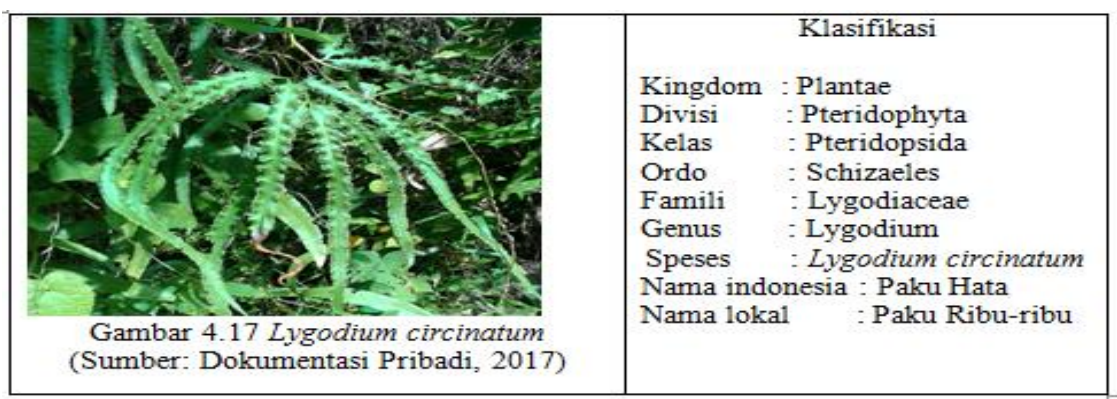

Spesies Lygodium circinatum termasuk dalam famili Lygodiaceae yang ditemukan di Kawasan Danau Aur dan dikenal dengan nama daerah paku riburibu, ditemukan ditempat yang terbuka dan dan menompang pada batang lain. Daunnya bertekstur tipis dan kuat ujungnya meruncing dan tepinya bergerigi. Akar dan batang berwarna coklat, berbentuk bulat, mempunyai daun yang berwarna hijau. Lygodium circinatum ini ditemukan pada suhu $28^{\circ} \mathrm{C}-31^{\circ} \mathrm{C}$ yang relatif normal untuk tumbuhan paku dan derajat keasaman atau $\mathrm{pH}$ tanah 5,11 yang berarti asam.

Tumbuhan ini ditemukan di hutan kerangas yang hidup di tempat-tempat terbuka yang mendapat sinar matahari langsung. Paku ini berakar di dalam tanah berwarna coklat. Lygodium circinatum tumbuh menjalar atau merambat pada tumbuhan lain yang berada di dekatnya. Batangnya berwarna coklat muda, berbentuk bulat, berukuran kecil dan sangat kuat. Tumbuhan ini mempunyai daun yang berwarna hijau. Daunnya bertekstur tipis dan kuat, ujungnya runcing dan tepinya bergerigi, sedangkan bagian abaksialnya berwarna lebih muda. Lygodium circinatum berbeda dengan paku lainnya karena mempunyai akar yang menjalar di tanah. Paku ini berkhasiat sebagai obat luka sehingga bisa untuk mengobatidari sengatan binatang melata seperti ular, lipan dan laba-laba dengan menggunakan getah pada paku ini (Purwanti, dkk. 2014).

3. Hasil pengamatan divisi Pteridophyta (paku) di kawasan Danau Aur Kabupaten Musi Rawas pada plot 2 terdiri dari 8 spesies Pteris biaurita, Nephrolepis exaltata, Nephrolepis cordifoli, Nephrolepis biserrata, Phymatosorus scolopendria, Selaginella wildenowii, Selaginella caudata dan Selaginella plana. Jenis spesies yang paling banyak ditemukan adalah jenis spesies Selaginella wildenowii, Selaginella caudata dan Selaginella plana. 
Suhu lingkungan $31,5^{\circ} \mathrm{C}$ dan derajat keasaman $\mathrm{pH}$ tanah 6,18 yang berarti asam. Hasil identifikasi kaenekaragaman divisi Pteridophyta (paku) pada plot 3 di Kawasan Danau Aur Kabupaten Musi Rawas sebagai berikut:

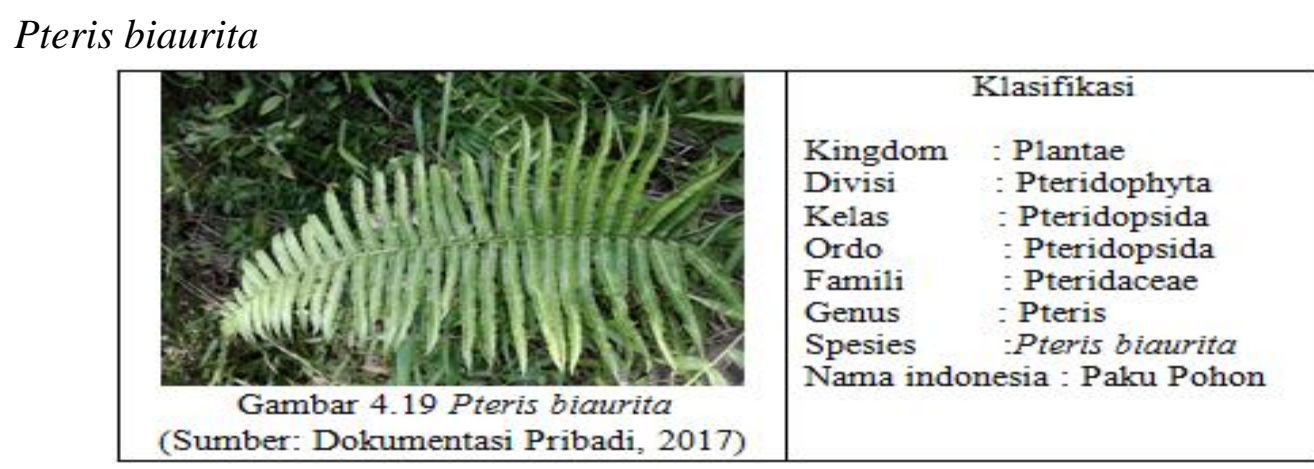

Termasuk famili Pteridaceae jenis Pteris biaurita, yang tumbuh ditempat yang lembab. Paku ini mempunyai batang yang pendek, tegak, ditutupi oleh akar-akar langsing, tangkai daun hijau, bagian atas bertekuk, tangkai anak daun dan tulang daun berlekuk dalam. Bagian ujung batang terdapat sisik dan bagian pangkal tangkai daun bewarna coklat tua, daun utama berjumlah 11 daun berhadapan dalam satu tangkai, setiap daun utama terbagi atas anak daun yang berjumlah 23 pasang helai daun, kedudukan daun utama sejajar. $\mathrm{pH}$ tanah adalah 6,18 yang berarti asam. Suhu lingkungan berkisar $28^{\circ} \mathrm{C}-31^{\circ} \mathrm{C}$ yang berarti suhu relatif normal untuk pertumbuhan paku.

Menurut Hartini (2006) Pteris biaurita biasanya terdapat didaratan rendah maupun daerah pegunungan, di tempat yang lembab dan ternaungi. Jenis ini tumbuh di daerah tropis dan berpotensi sebagai tanaman hias.

Nephrolepis exaltata

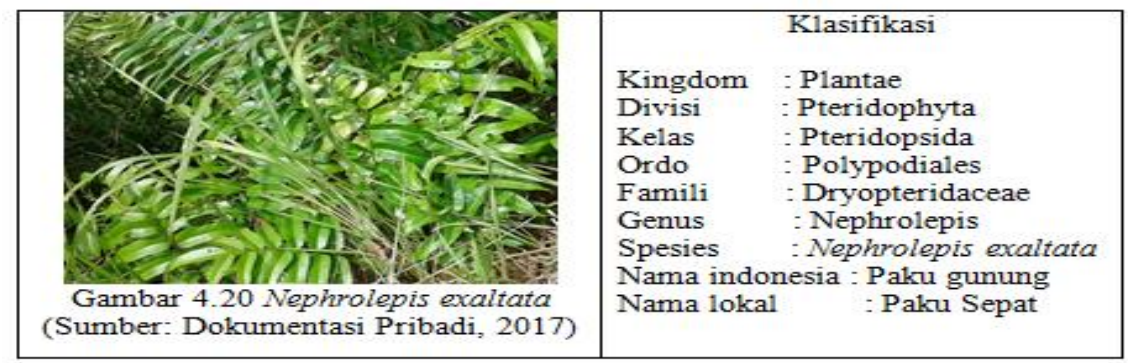

Termasuk paku tanah, akar rimpang tegak, dan berdaun lebat. Termasuk kedalam famili Dryopteridaceae yang ditemukan di Kawasan Danau Aur, ditemukan pada tempat yang lembab dengan suhu yang panas. Anak daun duduk dan berbentuk pita daging daun tebal, berdasarkan $\mathrm{pH}$ tanah yang dilihat pada plot tempat di temukan paku Nephrolepis exaltata bahwa paku Nephrolepis exaltata di temukan pada $\mathrm{pH}$ tanah 6,18 yang berarti asam. Suhu lingkungan yang di lihat pada plot tempat ditemukan paku Nephrolepis exaltata bahwa paku Nephrolepis exaltata hidup di temukan pada suhu $28^{\circ} \mathrm{C}$ $31^{\circ} \mathrm{C}$ yang berarti suhu relatif normal untuk pertumbuhan paku. Panjang tangkai daun sekitar 10-60 cm, pangkalnya gundul atau bersisik jarang. Anak 
daun fertil lurus atau berbentuk sabit, pada pangkal tepi atas bertelinga, tepinya beringit bergigi ringan.

Rhizoma menjalar, tangkai daun telanjang panjangnya $10-15 \mathrm{~cm}$, daun panjangnya $20-80 \mathrm{~cm}$, lebar $8-15 \mathrm{~cm}$, anak daun letaknya berdekatan, bentuk ujung daun runcing, bentuk tepi rata atau berkerut, pangkal bagian atasnya bertelinga, anak daun berbentuk pita, daging daun agak tebal, permukaan daun telanjang, sorus letaknya dekat tepi anak daun, indisium berbentuk ginjal. Terdapat pada daerah yang tidak begitu kering, hutan belukar, rimba rumput, tepi hutan. Nephrolepis exaltata memiliki manfaat sebagai penyerap paling efektif, terutama formaldehid, xylene dan karbon monoksida (Sari \& Rosada, 2009).

\section{Nephrolepis cordifolia}

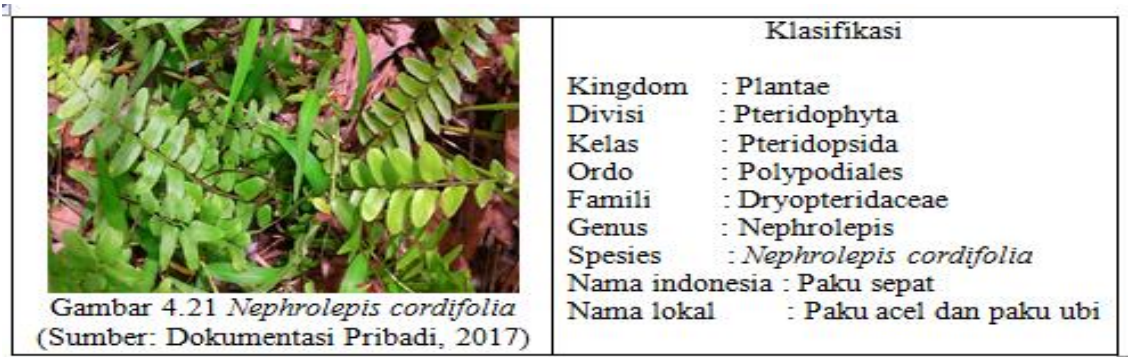

Termasuk paku tanah atau epifit, akar rimpang tegak, bedaun rapat yang termasuk kedalam famili Dryopteridaceae yang ditemukan di Kawasan Danau Aur. Anak daun tersusun dan sangat rapat, dengan pangkal berbentuk meruncing. Daun duduk dan hampir duduk, Nephrolepis cordifolia ini ditemukan pada suhu $28^{\circ} \mathrm{C}-31^{\circ} \mathrm{C}$ yang berarti suhu relatif normal untuk pertumbuhan paku dan derajat keasaman 6,18 yang berarti asam. Umbi pengeram bersisik, panjang 1-3 $\mathrm{cm}$. Daun duduk atau hampir duduk 25-100 kali 3-8 cm, poros dengan sisik coklat. Berbentuk serupa rambut, tangkai daun 2,5-20 cm. Anak daun berjejal rapat, kerapkali tersusun serupa genting, dengan pangkal berbentuk jantung atau terpancung, pada tepi atas kerapkali bertelinga, yang terbawah sangat kecil. Anak daun fertil 1,5-4 kali 0,5-1,5 cm, beringgit bergigi tidak dalam, urat daun sejajar yang berakhir dalam sorus atau pori air. Nephrolepis cordifolia memiliki manfaat sebagai tanaman hias dan dapat dijadikan sebagai obat (Steenis, 2013).

\section{Nephrolepis biserrata}

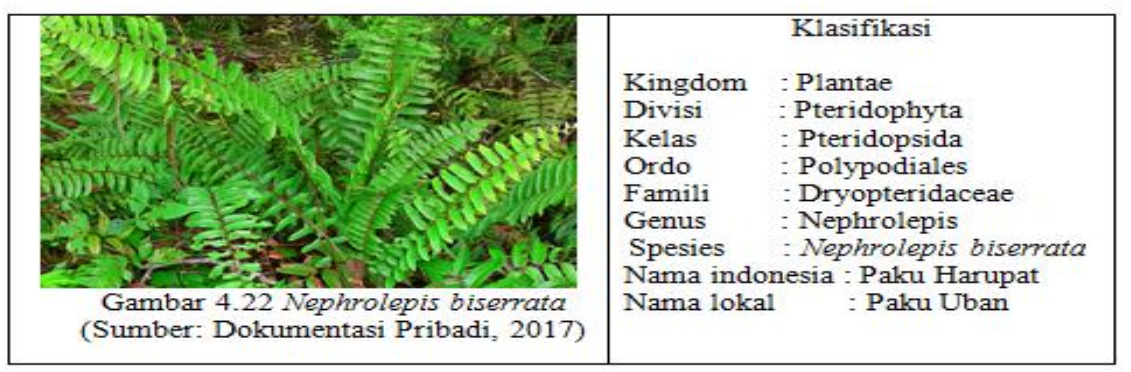

Paku tanah, yang termasuk kedalam famili Dryopteridaceae yang ditemukan di Kawasan Danau Aur. Nephrolepis biserrata ini ditemukan pada 
suhu $28^{\circ} \mathrm{C}-31^{\circ} \mathrm{C}$ yang berarti suhu relatif normal untuk pertumbuhan paku dan derajat keasaman 6,18 yang berarti asam. tinggi 0,6-4,5 m. Akar tegak, berdaun rapat. Tangkai daun memilki panjang 10-50 cm, tertutup oleh sisik yang berwarna coklat muda dan mudah rontok. Daun berbentuk lanset garis, dan pangkal meruncing, tepi atas bertelinga, ujung meruncing, anak daun muda berambut halus (Steenis, 2013).

\section{Phymatosorus scolopendria}

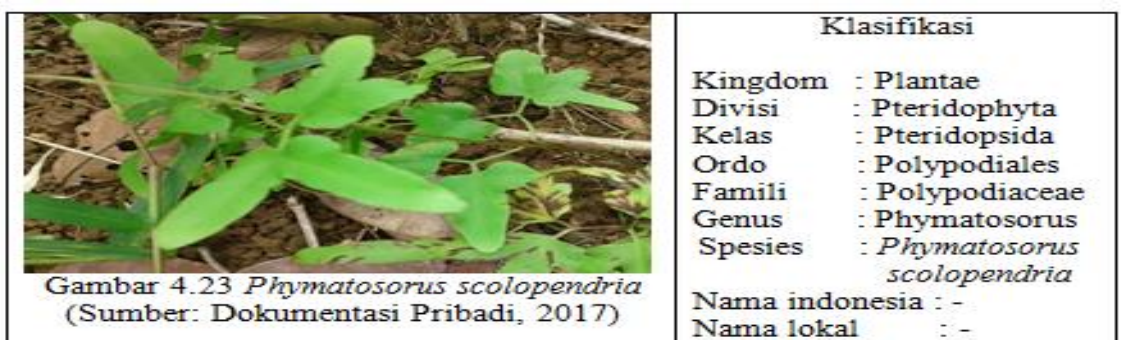

Famili Polypodiaceae yang ditemukan di Kawasan Danau Aur yaitu spesies Phymatosorus scolopendria. Tumbuhan paku ini memiliki perawakan herba. Akarnya merambat dan bewarna coklat di bagian tepi. Batang berbentuk rimpangnya dan bersisik. Memiliki tangkai daun yang ramping dengan panjang $16,4 \mathrm{~cm}$. Phymatosorus scolopendria ini ditemukan pada suhu $28^{\circ} \mathrm{C}-31^{\circ} \mathrm{C}$ yang berarti suhu relatif normal untuk pertumbuhan paku dan derajat keasaman 6,18 yang berarti asam. Daun memiliki panjang $26 \mathrm{~cm}$, lebar 4,8 cm, ujung daun meruncing dan tepi daun bertoreh. Tumbuhan paku ini mempunyai sorus yang terletak di bawah permukaan daun, bentuknya bulat, tersusun berbaris atau tidak beraturan. Sorusnya masuk kedalam lekukan yang menonjol diatas permukaan daun. paku ini adalah salah satu jenis paku yang dapat ditemukan di daratan rendah dan didasar pohon, membentuk koloni besar. (Tjitrosomo, 2010).

\section{Selaginella wildenowii}

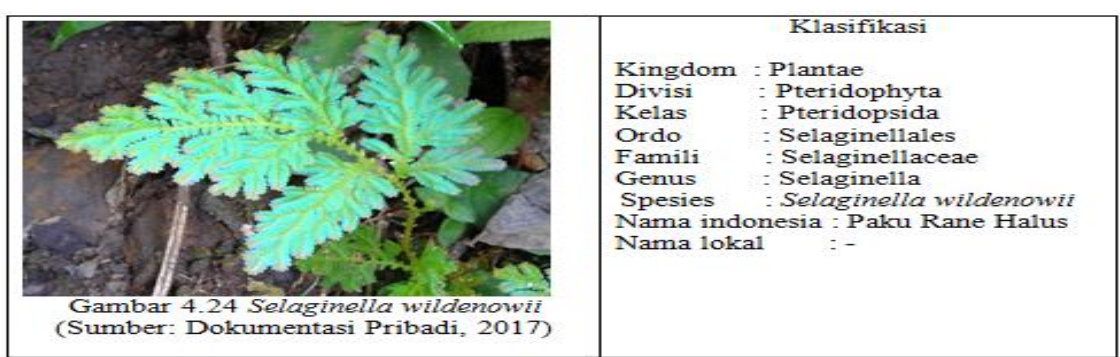

Selaginella wildenowii termasuk dalam famili Selaginellaceae yang ditemukan di Kawasan Danau Aur, dan dikenal dengan nama daerah paku rane. Paku ini hidupnya berumpun dengan akar berwarna putih ke abu-abuan. Batangnya tegak memiliki warna coklat. Jenis ini mempunyai daun berukuran kecil. Daunnya warna kuning kehijauan, Selaginella wildenowii ini ditemukan pada suhu $28^{\circ} \mathrm{C}-31^{\circ} \mathrm{C}$ yang berarti suhu relatif normal untuk pertumbuhan paku dan derajat keasaman 6,18 yang berarti asam. Sporangium berkelompok membentuk strobilus yang terletak diujung daun berwarna hijau muda. 
Selaginella wildenowii mempunyai akar berwarna abu-abu. Daun kecil berwarna kuning kehijauan. Strobilus diujung percabangan (Purwanti, 2014). Paku ini berbentuk herba memanjat, panjang 1-5 m. Batang, pada bagian terbawah daun berbaris 4, jarak satu dengan yang lainnya berjauhan. Daun dari baris terdepan sangat kecil, melekat batang daun dari kedua belah sisi lebih besar, berjarak lebar, mudah rontok, berbentuk sabit lemah. Daun fertil bulat telur lebar, dengan ujung lancip yang pendek, berjejal rapat menjadi bulir panjangnya 0,5-2,5 cm (Steenis, 2013:79).

Selaginella caudata

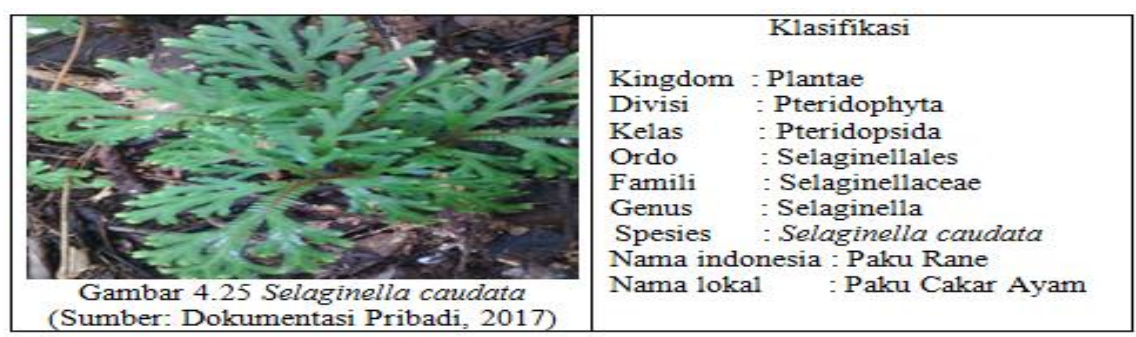

Famili Selaginellaceae jenis Selaginella caudata, ditemukan ditempat yang lembab dan berbatuan. Daun tersusun berhadapan, memiliki batang yang berdiri tegak dan sebagian berbaring, batang bercabang menggarpu, daun bewarna hijau. Selaginella caudata ini ditemukan pada suhu $28^{\circ} \mathrm{C}-31^{\circ} \mathrm{C}$ yang berarti suhu relatif normal untuk pertumbuhan paku dan derajat keasaman 6,18 yang berarti asam. Memiliki akar yang keluar dari bagian batang yang tidak memiliki daun dan dinamakan pendukung akar. Daun tersususun berhadapan dengan sepasang ligula. Ligula merupakan alat penghisap air (misalnya tetes air hujan) dan seringkali dengan perantaraan suatu trakeida mempunyai hubungan dengan batas pembuluh pengangkutan. Habitat paku ini pada tanah atau dapat dapat juga sebagai epifit pada bebatuan.

Selaginella plana

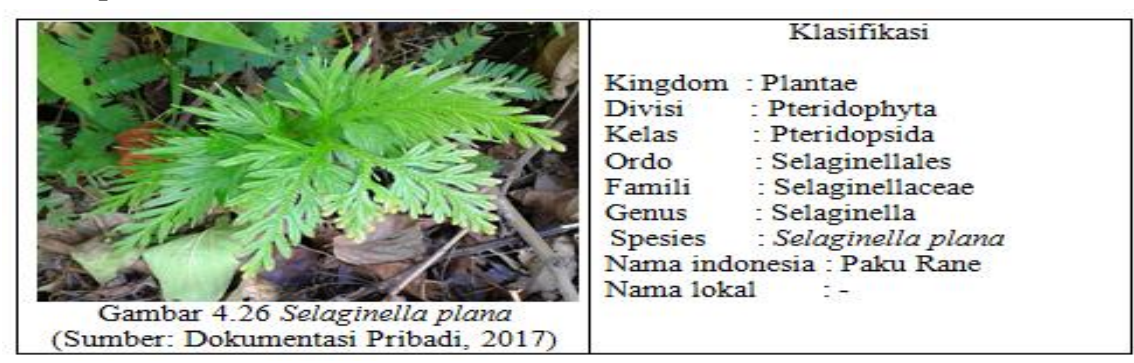

Selaginella plana termasuk dalam famili Selaginellaceae yang ditemukan di Kawasan Danau Aur. Paku ini termasuk jenis paku epifit yang menempel pada batu atau pohon-pohon besar. Pertumbuhan merayap, daun berukuran sangat kecil tersusun melingkari batang. Spora terdapat pada ujung daun. Selaginella hidup pada suhu $28^{\circ} \mathrm{C}-31^{\circ} \mathrm{C}$ yang berarti suhu relatif normal untuk pertumbuhan paku dan derajat keasaman 6,18 yang berarti asam. Jenis paku ini bisa dijadikan sebagai tanaman hias karena bentuknya yang cantik.(Arini dan Kinho, 2012). 


\section{SIMPULAN}

Berdasarkan hasil penelitian yang telah dilakukan maka dapat disimpulkan hasil Identifikasi Divisi Pteridophyta (Paku) di Kawasan Danau Aur Kabupaten Musi Rawas ditemukan 5 Ordo dan 12 Genus Yaitu: Ordo Polypodiales adalah Pteris, Stenochlaena, Ploecnemia, Nephrolepis, Diplazium, Phymatosorus, Asplenium dan Davallia. Ordo Gleicheniales adalah Gleichenia. Ordo Schizaeles adalah Lygodium. Ordo Filicales adalah Christella, dan Ordo selaginellales adalah Selaginella.

\section{DAFTAR PUSTAKA}

Arini, D. 1. D. \& Kinho, J. (2012). Keragaman Jenis Tumbuhan Paku (Pterydophyta) di Cagar Alam Gunung Ambang Sulawesi Utara. Balai Penelitian Kehutanan Manado, 2 (1), 17-40.

Hartini, S. (2006). Tumbuhan Paku di Cagar Alam Sago Malintang, Sumatera Barat serta Aklimatisasinya di Kebun Raya Bogor. Biodiversitas, 7(3), 230236.

Mardiastutik, W. E. (2010). Mengenal Tumbuhan. Jakarta: Mitra Utama.

Purwanti, U. (2014). Ekplorasi Paku-pakuan (Pteridophyta) di Kawasan Cagar Alam Mandor Kabupaten Landak. Protobiont, 3 (2), 155-165.

Sari, D. Y. I. \& Rosada, A. (2009). Identifikasi Tumbuhan Paku di Perkebunan Karet (Havea brasiliensis) di Desa Tanjung Raya Kecamatan Rambang Prabumulih Sumatera Selatan. Jurnal Sainmatika. 2 (6), 23.

Setyosari, P. (2015). Metode Penelitian Pendidikan dan Pengembangan. Jakarta: Pranamedia Group.

Steenis, V. C.G.G.J. (2013). Flora. Jakarta: Penebar Swadaya.

Suwila, M. T. (2015). Identifikasi Tumbuhan Epifit Berdasarkan Ciri Morfologi dan Anatomi Batang Di Hutan Perhutani Sub BKPH Kedunggalar, Sonde dan Natah. Jurnal Florea, 2 (1) 47-50.

Tjitrosoepomo, G. (2011). Taksonomi Tumbuhan. GadjahMada University Press. Yogyakarta.

Tjitrosomo, S. S. (2010). Botani Umum 3. Bandung: Angkasa.

Ulum, B. F. \& Setyati, D. (2015). Tumbuhan Paku(Pteridophyta) Epipit di Gunung Raung, Banywangi, Jawa Barat.Jurnal Ilmu Dasar. 16 (1), 7-12.

Yusuf. M. A. M. (2009). Keanekaragaman Tumbuhan Paku di Kawasan Cagar Alam Gebungan Kabupaten Semarang. Skripsi. Universitas Semarang, 22. 